Indexed by

\title{
THE EFFECT OF NATURAL FIBER (BANANA FIBER) ON THE MECHANICAL PROPERTIES OF SELF-COMPACTING CONCRETE
}

Crossref

\section{Nursiah Chairunnisa \\ Lambung Mangkurat University, Engineering Faculty, Civil Engineering Study Program, Banjarbaru, Indonesia}

\author{
Ratni Nurwidayati \\ Lambung Mangkurat \\ University, Engineering \\ Faculty, Civil Engineering \\ Study Program, Banjarbaru, \\ Indonesia
}

\author{
Gusti Muhammad Madani S \\ Lambung Mangkurat \\ University, Engineering \\ Faculty, Civil Engineering \\ Study Program, Banjarbaru, \\ Indonesia
}

Key words: self-compacting concrete, banana fiber, mechanical properties, delignification process doi:10.5937/jaes0-32879

Cite article:

Chairunnisa N., Nurwidayatii R., Muhammad Madani S G. (2022) THE EFFECT OF NATURAL FIBER (BANANA FIBER) ON THE MECHANICAL PROPERTIES OF SELF-COMPACTING CONCRETE, Journal of Applied Engineering Science, 20(2), 331 - 338, DOI:10.5937/ jaes0-32879 


\title{
THE EFFECT OF NATURAL FIBER (BANANA FIBER) ON THE MECHANICAL PROPERTIES OF SELF-COMPACTING CONCRETE
}

\author{
Nursiah Chairunnisa*, Ratni Nurwidayati, Gusti Muhammad Madani S \\ Lambung Mangkurat University, Engineering Faculty, Civil Engineering Study Program, \\ Banjarbaru, Indonesia
}

Self-compacting concrete is an innovative concrete technology with higher flowability properties by adding the mineral admixtures such as superplasticizers and not necessary to vibrate concrete. The banana fibers were used in this investigation because banana fiber is an environmentally friendly material with good properties compared to synthetic fiber. The experimental test consisted of two phases of research, i.e., preliminary research, which had the aim to investigate the appropriate percentage of superplasticizer in the mixed composition of self-compacting concrete. The percentages of superplasticizers were $0.7 \%, 1 \%$, and $1.4 \%$. The second phase of research on the effect of additional banana fiber on self-compacting concrete was carried out, examining workability, compressive strength, and the splitting tensile strength of concrete. In this research, the percentages of fiber were $0.12 \%, 0.3 \%$, and $0.5 \%$ of the cement weight, and evaluated the effect of fiber treatment. The treated fibers mean that the fiber is immersed in $\mathrm{NaOH}$ solution or named as a delignification process. The hardened concrete specimen was used for determining the mechanical strengths, such as the compressive strength and split tensile strength tests. The test results found that the optimum value for superplasticizer dosage was $0.7 \%$ of cement weight, which can fulfill the whole criteria of fresh concrete and hardened SCC concrete. Furthermore, the specimen with the adding banana fiber of $0.12 \%$ by cement weight and treated fiber indicated a decrease in workability. Compared to the control concrete, it inversely increased compressive strength up to $44.36 \%$ and tensile strength up to $17.78 \%$.

Key words: self-compacting concrete, banana fiber, mechanical properties, delignification process

\section{INTRODUCTION}

\section{Self Compacting Concrete}

The innovative concrete technology, which improved flow easily and homogeneity without compacting or vibrating concrete to fulfill the formwork by adding the mineral admixtures, can be implemented for self-compacting concrete, SCC [1-5] dan two-stage concrete [6-13]. According to Dehn et al. [14], the basic principle concept on self-compacting concrete mix design is the relation between superplasticizer (SP) and fresh concrete characteristics, as shown in Figure 1. Usually, the superplasticizer on SCC is required for dispersing cement particles and separating them into fine particles. Moreover, the percentages of superplasticizer (SP) and aggregates types play an important role in the mix design of SCC [15]. According to Persoon [16], the flowability of fresh concrete would be increased with the greater proportion of fine aggregate if compared to the coarse aggregate, the more in the mix design of SCC. However, if the percentage of fly ash is too much in mix composition, the compressive strength of concrete would be decreased. If too much coarse aggregate in the mix design, the segregation risk concrete would be increased too. So the requirement of adding mineral admixtures to avoid bleeding and segregation, such as fly ash, limestone powder, silica fume, or other admixture, can solve this problem. The coarse aggregate composition in conventional con-

*nursiah.chairunnisa@ulm.ac.id

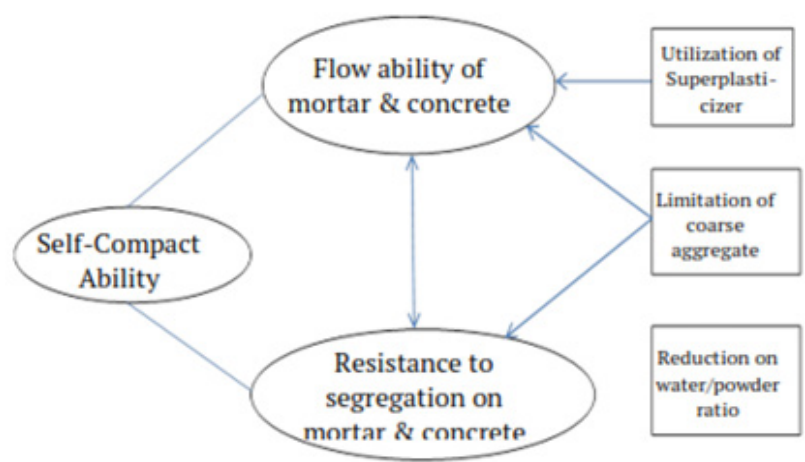

Figure 1: Basic principle concept on self-compacting concrete production (Dehn, et al., 2000)

crete is approximately $70-75 \%$ of total concrete volume. Whereas for SCC producing, the amount of coarse aggregate is being limited to less than $50 \%$ of total concrete volume [17].

\section{Natural fibre}

Applying natural fiber such as rice husk, coconut fiber, or an artificial natural fiber such as steel ash as an admixture in conventional concrete is a well-known concept in construction technology. The main intention of utilizing natural fibers is to alleviate the environmental effect produced by non-biodegradables of synthetic fibers. Natural fibers are used as an additive in concrete mixing due to 
their non-abrasive, non-toxic, lightweight, biodegradable properties, environmentally friendly materials, and good properties compared to synthetic fiber [18-19]. Banana fiber is one of the agricultural waste materials from banana cultivation. Banana fiber belongs to the alternatives natural fibers that produce good mechanical properties. Several studies have shown that adding natural or non-natural waste to concrete mixtures can have several advantages, such as reducing the volume of conventional concrete raw materials and increasing the mechanical properties of concrete. One of the natural additives that can be used is banana fiber. Previous studies show that the addition of banana stem fibers to the concrete can increase the mechanical strength of the concrete [20-21]. Previous research by Chandak et al. [22] investigated that the addition of banana fiber by $0.5 \%$ for SCC increased the compressive strength of concrete by $14 \%$ compared to normal concrete. This result also decreased the slump value of the fibrous SCC concrete, thereby reducing the workability value. Furthermore, the addition of fiber of $0.3 \%, 0.5 \%, 0.7 \%$, and $1 \%$ with the respective resulted for compressive strength of 30.8 $\mathrm{MPa}$, 38.7 MPa, 35 MPa, and 33 MPa. Moreover, for tensile strength, the results were 2.4 MPa, 2.54 MPA, 2.72 $\mathrm{MPa}$, and 2.9 MPa, respectively. The results obtained that compressive strength continues to increase with the fiber content of banana stalks, and the optimum variation is the addition of $0.5 \%$ banana stalk fiber [23]. In the current study, the experimental test was conducted to evaluate the appropriate percentages of superplasticizer in CSS composition, the optimum percentage of banana fiber in the SCC mix design, and the treatment effect on banana fiber using alkali. The hypothesis stated that banana fiber subjected to alkaline treatment had higher mechanical strength than can be used for self-compacting concrete.

\section{MATERIAL AND METHOD}

\section{Test of Agregate}

Physical characteristics of fine and coarse aggregates are determined first in Table 1 and Table 2. The particle size distribution of fine and coarse aggregates is plotted in Fig.2. Moreover, the characteristic of cement can be tabulated as Table 3.

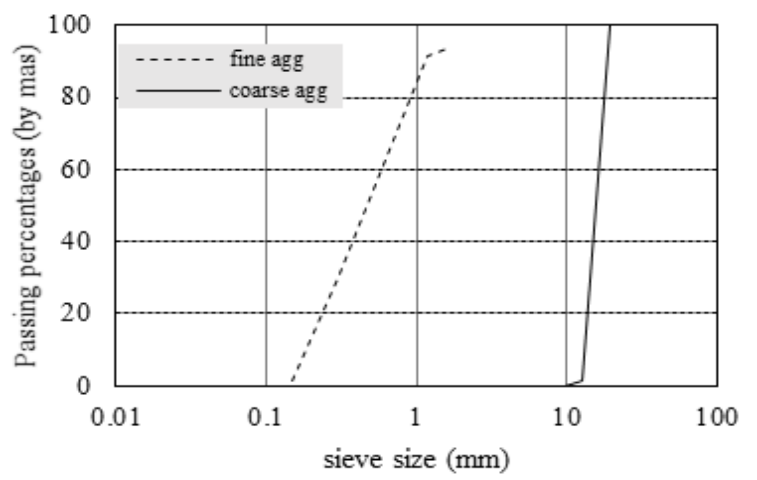

Figure 2: Sieve analysis of fine and coarse aggregate
Table 1: Characteristic of fine aggregates

\begin{tabular}{|c|c|c|}
\hline Characteristic & Observed value & Code \\
\hline Name & Barito sand & - \\
\hline Type & Mild sand & - \\
\hline Grade Zone & III & - \\
\hline Spesific gravity & $2.63 \mathrm{gr} / \mathrm{cm}^{3}$ & SNI 1970:2016 \\
\hline Water absorption & $2.98 \%$ & SNI 1970:2016 \\
\hline Fineness modulus & 3.20 & \\
\hline
\end{tabular}

Table 2: Characteristic of coarse aggregates

\begin{tabular}{|c|c|c|}
\hline Characteristic & Observed value & Code \\
\hline Name & Lok Bangkal & \\
\hline Water absorption & $1.13 \%$ & SNI 1969:2016 \\
\hline Spesific gravity & $2.59 \mathrm{gr} / \mathrm{cm}^{3}$ & SNI 1969:2016 \\
\hline Abrasion value & $36 \%$ & SNI 2417:2018 \\
\hline Fineness modulus & 6.98 & \\
\hline
\end{tabular}

Table 3: Characteristic of cement

\begin{tabular}{|c|c|c|}
\hline Characteristic & Observed value & Code \\
\hline Type & PCC & SNI 2531:2015 \\
\hline Spesific gravity & $3.37 \mathrm{gr} / \mathrm{cm} 3$ & SNI 03-6826-2002 \\
\hline $\begin{array}{c}\text { Normal } \\
\text { consistency }\end{array}$ & $26.6 \%$ & ASTM C403 \\
\hline $\begin{array}{c}\text { Innitial setting } \\
\text { time }\end{array}$ & 83.3 minutes & ASTM C403 \\
\hline $\begin{array}{c}\text { Final setting } \\
\text { time }\end{array}$ & 150 minutes & \\
\hline
\end{tabular}

\section{Mix Design of SCC}

There is no standard method for SCC mix design. According to EFNARC 2005 [24], academic institutions and companies have developed their mixed proportioning methods. Due to the lack of standardization for self-compacting concrete mix designs in Indonesia, this study carried out a mix design based on the Indonesian Standart of SNI 03-2834-2000 and SNI 7656:2012, which satisfied the requirements of EFNARC 2005 guidelines. The concrete test was carried out by using EFNARC 2005 for investigating fresh concrete of SCC that consists of filling ability, viscosity, and passing ability test. ASTM - C 39 was applied for identifying the compressive strength of hardened cylindrical concrete specimens. The splitting tensile strength is determined by following ASTM - C 293. The compressive strength and splitting tensile strength tests were conducted 28 days after curing. There were two stages of the research, i.e., preliminary research for discovering the optimum percentage of superplasticizer in the mixture of SCC based on composition constituent materials, described in Table 4. This research aims to investigate the adding of natural fiber (banana fiber) with 
various percentages of fiber for SCC. The mix composition of SCC will be developed based on the optimum result from preliminary research in terms of specimen behavior in fresh concrete based on EFNARC [24] and hardened concrete of SCC.

Table 4: Self-compacting concrete mix composition for preliminary research

\begin{tabular}{|c|c|}
\hline Materials & Composition \\
\hline water & $244 \mathrm{Itr}$ \\
\hline Cement & $518 \mathrm{~kg}$ \\
\hline Fine aggregate (FA) & $882 \mathrm{~kg}$ \\
\hline Coarse aggregate (CA) & $752 \mathrm{~kg}$ \\
\hline \multirow{5}{*}{ Viscocrete 1003 (Sp) } & $\begin{array}{c}\text { SCCSP0.7 }=0.7 \% \text { of } \\
\text { cement weight }\end{array}$ \\
\cline { 2 - 2 } & $\begin{array}{c}\text { SCCSP1.0 }=1.0 \% \text { of } \\
\text { cement weight }\end{array}$ \\
\cline { 2 - 2 } & $\begin{array}{c}\text { SCCSP1.4 = } 1.4 \% \text { of } \\
\text { cement weight }\end{array}$ \\
\hline
\end{tabular}

\section{Deligniciation treatment of Banana Flber}

In order to remove lignin and hemicellulose that have responsibility for the instability of fibers, alkali treatment or deligniciation of banana fibers has been used by using $\mathrm{NaOH}$ solutions to improve the performance of banana fibers. Processing of deligniciation treatment of fibers can be depicted in Figure 3.

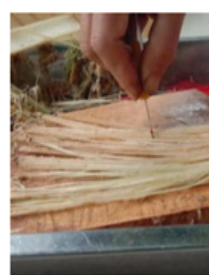

(a)

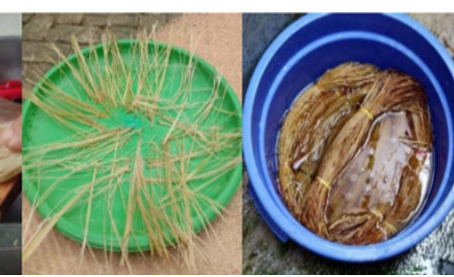

(b) (c)

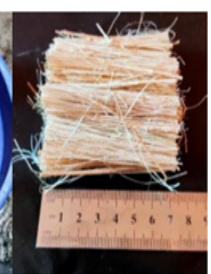

(d)
Figure 3: natural fiber (a) banana stem plants,

(b) natural drying of banana fibers, (c) delignification treatment, (d) cutting $7 \mathrm{~cm}$ of banana fibers

From Fig 3, the banana fibers were drawn from the banana stem plants. Firstly, banana fibers were extracted using a needle or pin. The banana fibers were dried under the sunlight for $3 \times 24$ hours (natural drying), and in this experiment, the banana fibers could be cutting for $7 \mathrm{~cm}$ [25] for untreated specimens. For delignification treatment of fiber, banana fibers were immersed in $5 \% \mathrm{NaOH}$ solution for 24 hours. After that, the treated banana fibers were washed and soaked with distilled water for 24 hours to remove the excess of $\mathrm{NaOH}$ at the surface of banana fibers. Afterward, the banana fibers would be dried under sunlight for 24 hours or dried oven at $110 \circ C$. Similarly, with the untreated specimen, the banana fibers could be cutting for $7 \mathrm{~cm}$.

\section{RESULT AND DISCUSSION}

\section{Fresh concrete}

For ensuring the workability and homogeneity of SCC, the slump-flow test was conducted. The target of slump flow should be between $520 \mathrm{~mm}$ until $900 \mathrm{~mm}$ [24]. The slump flow of SCC specimens was measured as $565 \mathrm{~mm}$, $600 \mathrm{~mm}$, and $630 \mathrm{~mm}$ for $0.7 \%, 1.0 \%$, and $1.4 \%$ of SP, respectively, as shown in Table 5. Moreover, as per EFNARC (2005), SCC can be classified on the criteria of slump-flow as a filling ability/flowability test. The process of the fresh concrete test can be shown in Figure 4.

Table 5: Slump flow specimens and superplasticizer dosages

\begin{tabular}{|c|c|c|}
\hline Specimen Code & $\begin{array}{c}\text { Dosage of sp } \\
(\%)\end{array}$ & $\begin{array}{c}\text { Slump flow } \\
(\mathrm{mm})\end{array}$ \\
\hline SCCSP0.7 & 0.7 & 565 \\
\hline SCCSP1.0 & 1.0 & 600 \\
\hline SCCSP1.4 & 1.4 & 630 \\
\hline
\end{tabular}

The fresh properties of mixes for all specimens were tabulated in Table 6 and Figure 5

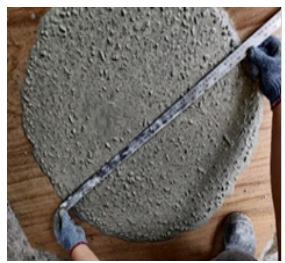

(a)

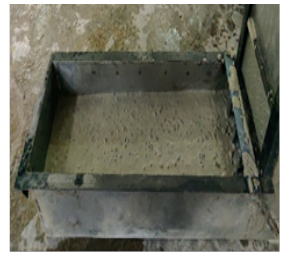

(b)

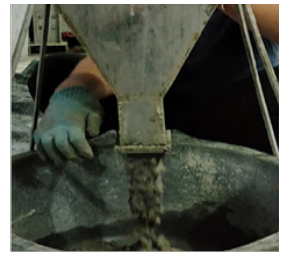

(c)
Figure 4: fresh concrete tests carried out on specimen (a) Slump flow test (b) L-box test. (c) V-funnel test

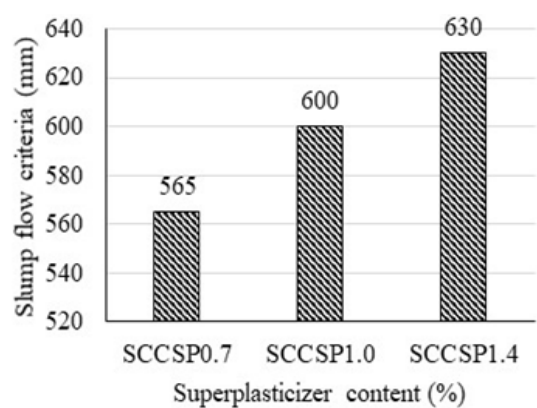

(a)

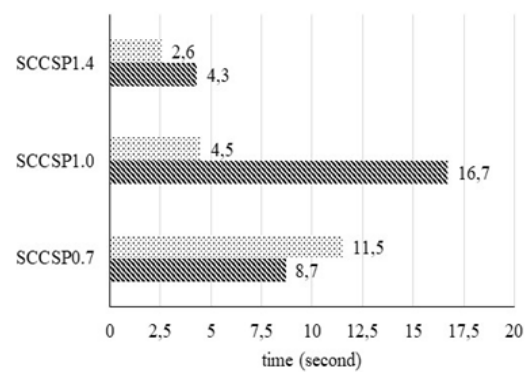

(b)

Figure 5: (a) The value of slump flow test, (b). The value of $V$ funnel and T-500 test 
Table 6: The Result of test properties and methods for evaluating of SCC Specimens

\begin{tabular}{|c|c|c|c|c|c|}
\hline \multirow{2}{*}{ Mix ID } & \multirow{2}{*}{$\begin{array}{c}\text { Superplasticizer } \\
\text { dosages (\%) }\end{array}$} & Filling ability/flowability class & \multicolumn{2}{|c|}{ Viscosity Class } & Passing ability class \\
\cline { 3 - 6 } & & Slump flow $(\mathrm{mm})$ & $\begin{array}{c}\text { V-Funnel } \\
\text { (second) }\end{array}$ & $\begin{array}{c}\text { T-500 } \\
\text { (second) }\end{array}$ & Lbox Test \\
\hline SCCSP0.7 & 0.7 & 565 & 8.7 & 11.5 & 1,0 \\
\hline SCCSP1.0 & 1.0 & 600 & 16.7 & 4.5 & 0,2 \\
\hline SCCSP1.4 & 1.4 & 630 & 4.3 & 2.6 & 0,4 \\
\hline
\end{tabular}

From the conducted tests, which are shown in Table 6 and Figure 5, the addition of a superplasticizer affected the fresh properties characteristic of SCC. The higher the superplasticizer content, the slump flow would be increased significantly. The fresh concrete test result showed that the highest diameter slump flow value was $630 \mathrm{~mm}$ on mix design with content Sp of $1.4 \%$. Howev$\mathrm{er}$, the superplasticizer content of $0.7 \%$ of cement weight as SCCSP0.7 specimens would then be applied for self-compacting concrete designing or as control specimens for further research because it can fulfill all SCC criteria in terms of passing ability, viscosity, and filling ability.

\section{Mix Design of Banana Fibre of SCC}

The mix design was developed based on the mix proportion of SCCSP0.7 specimens from preliminary research. The mix compositions of utilizing an addition of natural fibre such as banana fiber in various percentages of $0.12 \%, 0.3 \%$, and $0.5 \%$ of cement weight in the composition of SCC mix design as main research can be tabulated in Table 7.

Table 7: The Mix Proportioning of Banana Fibre SCC

\begin{tabular}{|c|c|c|c|c|c|c|c|c|}
\hline \multirow{2}{*}{ Mix ID } & \multicolumn{4}{|c|}{ constituents Materials $\left(\mathrm{kg} / \mathrm{m}^{3}\right)$} & \multirow{2}{*}{$\begin{array}{l}\mathrm{SP} \\
\%\end{array}$} & \multicolumn{2}{|c|}{ Banana Fiber } & \multirow{2}{*}{$\begin{array}{c}\text { Treatment of Banana } \\
\text { Fibre }\end{array}$} \\
\hline & cement & $\mathrm{CA}$ & FA & Water & & $\%$ & $\mathrm{gr} / \mathrm{m}^{3}$ & \\
\hline SCCSP0.7 & 518 & 752 & 882 & 244 & 0.7 & 0 & 0 & - \\
\hline SCCSP0.7_A & 518 & 752 & 882 & 244 & 0.7 & 0.12 & 15.54 & Normal \\
\hline SCCSP0.7_B & 518 & 752 & 882 & 244 & 0.7 & 0.3 & 38.86 & Normal \\
\hline SCCSP0.7_C & 518 & 752 & 882 & 244 & 0.7 & 0.5 & 64.77 & Normal \\
\hline SCCSP0.7_D & 518 & 752 & 882 & 244 & 0.7 & 0.12 & 15.54 & delignification \\
\hline SCCSP0.7_E & 518 & 752 & 882 & 244 & 0.7 & 0.3 & 38.86 & delignification \\
\hline SCCSP0.7_F & 518 & 752 & 882 & 244 & 0.7 & 0.5 & 64.77 & delignification \\
\hline
\end{tabular}

\section{Natural Fibre of SCC Result}

\section{Fresh Concrete of Banana Fiber SCC}

The characteristic of SCC Based on the fresh concrete with adding the percentage of banana fibers was shown in this research. As per EFNARC [24], SCC can be classified on slump-flow were tabulated in Table 8 and Figure 6 . Based on the results of the tests carried out, it can be seen that the variation added to banana stem fiber has decreased in its overall workability. (Only SCCSP0.7 and SCCSP0.7_A fulfill EFNARC 2005 code for slump flow criteria) It can be concluded that the addition of natural fiber can reduce the workability of the specimen with and without the delignification process. The effect of the delignifacition of fiber through the workability of all specimens can be shown in Fig.6(a).

\section{Hardened concrete of SCC}

The compressive strength of SCC after the curing period of 7,14 , and 28 days are the average compressive strength of SCCSP0.7 and SCCSP1.4 These are shown in Figs. 7. The results exhibited that a gradual increase in strength with the age of curing days. The compressive strength of the SCCSP0.7 specimen with $0.7 \%$ and $1.4 \%$ of superplasticizer were determined as $32.67 \mathrm{MPa}$ and $35.14 \mathrm{MPa}$. The result indicated that the percentage change in compressive strength performance for the SCCSP1.4 specimen is $7.56 \%$ higher than the SCCSP0.7 specimen with a lower dosage of admixtures, as shown in Fig.5(b). A total of 60 cylinder samples were used, consisting of 45 cylinder samples for the compression test and 15 cylinders samples for the splitting test. The hardened concrete test for compression test was 
Table 8: The Result of Fresh Concrete of SCC Specimens

\begin{tabular}{|c|c|c|c|}
\hline Mix ID & Banana fiber (\%) & Treatment & Slump flow test $(\mathrm{mm})$ \\
\hline SCCSP0.7 & 0 & - & 565 \\
\hline SCCSP0.7_A & 0.12 & Normal & 522.5 \\
\hline SCCSP0.7_B & 0.3 & Normal & 325 \\
\hline SCCSP0.7_C & 0.5 & Normal & 307 \\
\hline SCCSP0.7_D & 0.12 & delignification & 375 \\
\hline SCCSP0.7_E & 0.3 & delignification & 317 \\
\hline SCCSP0.7_F & 0.5 & delignification & 310 \\
\hline
\end{tabular}

28 days test. The compressive strength test of all specimens can be tabulated in Table 9 and Figs. 7 carried out based on ASTM C-39 for 7, 14, and 28 days test. Splitting tensile test determined by ASTM C-293 for

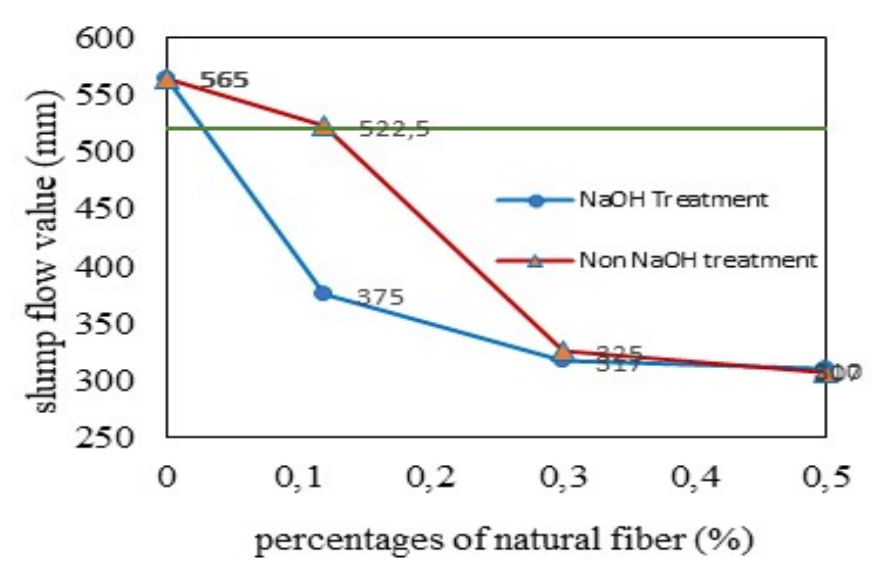

(a) The slump flow value test
Figure 6 (a) The slump flow value in different percentages dosage of banana fibers, (b) The compressive strength of specimen in different dosages of superplasticizer

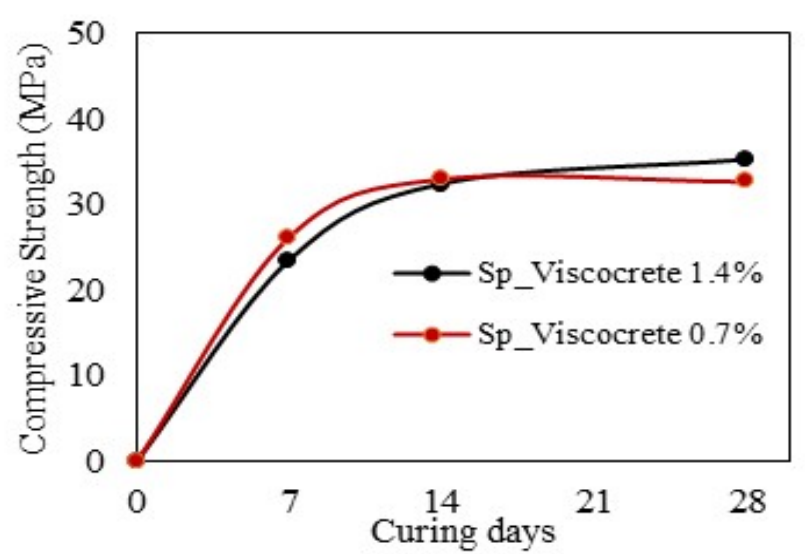

(b) compressive strength of specimens

Table 9: The Result of Hardened Concrete of Specimens

\begin{tabular}{|c|c|c|c|c|c|}
\hline \multirow{2}{*}{ Mix ID } & \multicolumn{3}{|c|}{ Compressive strength test } & \multirow{2}{*}{$\frac{\text { Splitting tensile test }(\mathrm{MPa})}{28 \text { days }}$} & \multirow{2}{*}{ treatment } \\
\hline & (MPa) & 14days & 28days & & \\
\hline SCCSP0.7 & 26.51 & 32.98 & 32.88 & 3.51 & Normal \\
\hline SCCSP0.7_A & 31.03 & 39.45 & 38.84 & 3.80 & Normal \\
\hline SCCSP0.7_B & 34.32 & 34.11 & 36.17 & 4.13 & Normal \\
\hline SCCSP0.7_C & 23.63 & 27.54 & 25.48 & 4.21 & Normal \\
\hline SCCSP0.7_D & 28.67 & 40.48 & 47.47 & 4.13 & delignification \\
\hline SCCSP0.7_E & 21.58 & 28.97 & 32.88 & 3.80 & delignification \\
\hline SCCSP0.7_F & 28.56 & 30.41 & 30.41 & 3.64 & delignification \\
\hline
\end{tabular}

Based on the result, the compressive strength of SCCSP0.7 as a control specimen is $32.88 \mathrm{MPa}$. The maximum compressive strength of $47.7 \mathrm{MPa}$ was recorded by SCCSPS0.7_D for 28 days, containing $0.12 \%$ of banana fibers and delignification treatment. Moreover, the higher compressive strength of $38.84 \mathrm{MPa}$ was also indicated by SCCSPS0.7_A, which similar dosage of banana fibers but the untreated process. Similar to SCCSPS0.7_C and SCCSPS0.7_F, which indicated that the higher compressive strength for specimen with delignification treatment. Moreover, SCCSPS0.7_E results differ from those of the others, which can be an error in the deligniciation process. From Figure 6 , it can be concluded that there is a significant effect of compressive strength for specimens with $\mathrm{NaOH}$ or delignification treatment. In line with [26][27], this result showed that banana fiber composite treated with $5 \% \mathrm{NaOH}$ concentration could improve the mechanical properties. Contrastly, the test results described that the compressive strength decreased gradually by increasing the percentage of banana fibers in both mixtures compositions (normal and delignification). Compared to the control 


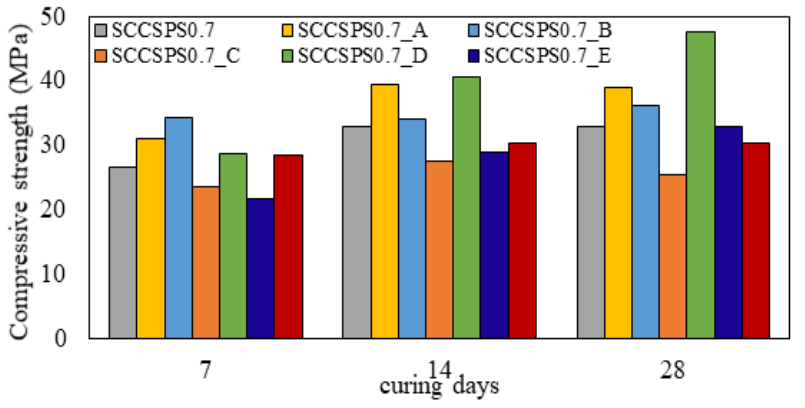

Figure 7: The compressive strength of specimens in different dosage percentages of banana fibers and treatment process

specimen, the additional banana fiber up to $0.3 \%$ still increases the compressive strength. It was observed that SCCSPS0.7_C and SCCSPS0.7_F, which higher dosage of banana fibers $(0.5 \%$ of cement weight), did not qualify the standard requirement of fresh concrete based on EFNARC 2005. Moreover, the compressive strength of SCCSPS0.7 E decreased slightly around $7.5 \% \mathrm{com}$ pared to the control specimen of SCCSPS0.7. Similar observations were studied by Chandak et.al.[22], which stated that the additional $0.5 \%$ banana fibers could alleviate workability and compressive strength. According to Fig.8, the specimen with the adding banana fiber of $0.12 \%$ by weight of cement and $\mathrm{NaOH}$ delignification indicated a decrease in the workability and inversely can

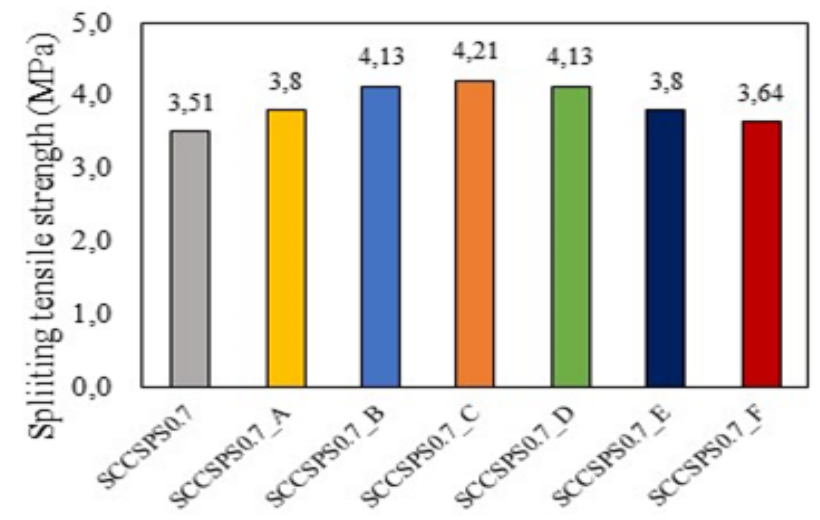

(a) The splitting tensile strength increase compressive strength up to $44.36 \%$ if compared to the variation of control concrete. Untreated specimens more decreased compressive strength than treated specimens using $\mathrm{NaOH}$ Solution. This could be attributed to the presence of a proper proportion of $\mathrm{NaOH}$ Concentration and alkalization reaction. Alkalization can remove certain parts of unwanted elements such as lignin, cellulose, hemicellulose, natural oils, wax from the surface of banana fibers. This treatment also could produce a rough and clean fiber surface which can enhance the surface area, bonding between fiber, and performance of banana fibers [28][29]. Tensile test results of untreated and treated banana fiber in SCC mixture increased compared to control specimen without banana fiber can be shown in Table 8(a).

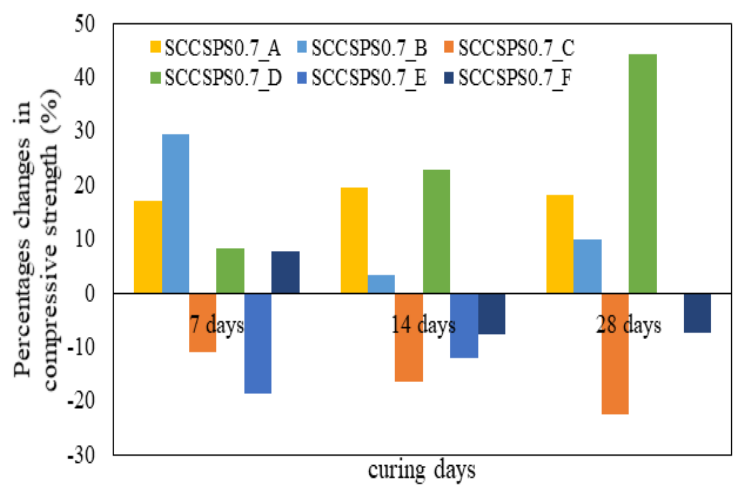

Figure 8: The percentage change in strength of specimen in different dosage of banana fibers and treatment process

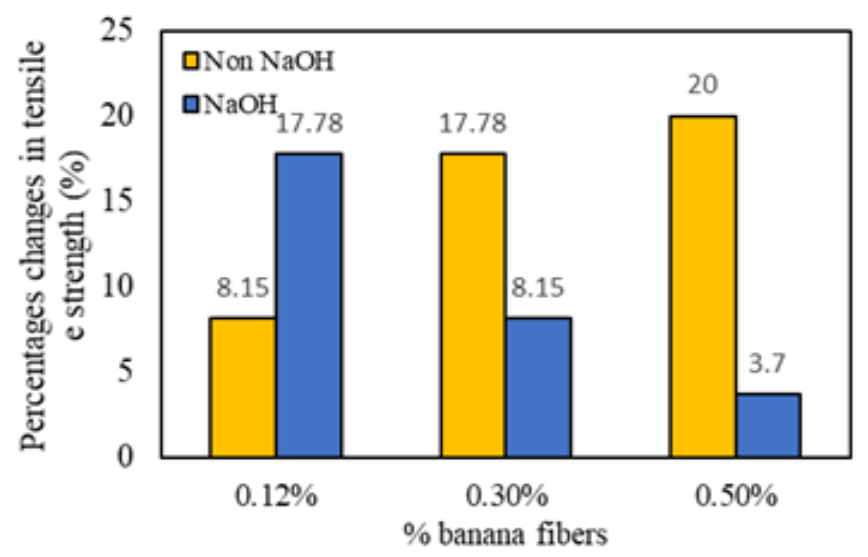

(b) The percentage change in tensile strength

Figure 9: The splitting tensile strength of specimens and the percentage change in tensile strength of the specimen

Figure $9(\mathrm{~b})$ showed the ultimate tensile strength of banana fiber specimens. It can be concluded that the addition of banana fiber in the SCC mixture could enhance the tensile strength of concrete. In this experiment, SCCSPS0.7_C, adding $0.5 \%$ of banana fiber, showed the highest tensile strength result at $4.21 \mathrm{MPa}$ and $20 \%$ higher than the control specimen SCCSPS0.7.

\section{CONCLUSION}

Based on the report research about the utilizing fiber for self-compacting concrete, the following conclusion are drawn:

1. The effect of adding superplasticizer to self-compacting concrete increases the values of the fresh concrete according to the EFNARC 2005

2. The effect of adding banana stem fiber to self-compacting concrete decreases in the values of the fresh concrete results

3. The delignification process using $\mathrm{NaOH}$ improves the SCC mechanical perfor-mance of specimens in terms of compres-sive and tensile strengths. 
4. Based on this experiment, it can be stated that the additional $0.12 \%$ of banana fiber that was alkaline treatment had a higher mechanical strength that can be applied for self-compacting concrete.

5. Based on the above result, it can be recommended to apply the utilizing banana fiber on two stages of concrete application.

\section{ACKNOWLEDGEMENT}

The authors gratefully acknowledge the financial support of Lambung Mangkurat University, Banjarmasin, Indonesia, under the scheme of DWM Grant, the agreement letter-number 009.6/UN8.2/PL/2021.

\section{REFERENCES}

1. Thirumalai, R.K., Murthi, P. (2015). Bagasse ash and rice husk ash as cement replacement in self-compacting con-crete. Gradevinar, vol. 67, no.1, 23-30, DOI: 10.14256/JCE.1114.2014.

2. Poongodi, K., Murthi, P., Awoyera, P.O., Gobinath, R. (2019). Effect of mineral admixtures on early age pro-perties of high performance concrete. IOP Conf. Series: Materials Science and Engineering 561, p.19.

3. Chopra, D., Siddique, R., Kunal. (2015). Strength permeability and micro-structure of self-compacting concrete containing rice husk ash. Biosystems Engineering, 130, 72-80. DOI: 10.1016/ j.biosystemseng.2014.12.005.

4. Wibowo, N.A. (2019). Designing of flow mortar design mix for self compacting concrete (SCC) with $\mathrm{FWC}=0.4$. Journal of The Civil Engineering Forum, vol. 5, no. 1, 39-45, DOI: 10.22 146/jcef.41014.

5. Eethar, T.D., Maysam, S.F.A. (2021). Effect of recycled materials and hybrid fibers on the properties of self-compacting concrete. Journal of Applied Engineering Science, vol. 19, no. 1, 262-269. DOI: 10.5937/jaes0-28558.

6. Chairunnisa, N., Fardheny, A.F. (2019). The study of flowability and the compressive strength of grout/ mortar proportions for preplaced concrete aggregate (PAC). MATEC Web of Conferences 280. DOI: 10.1051/matec-conf /201928004010

7. Murali G., Abid S. R., Abdelgader, H.S., Amran Y.H.M., Shekarchi, M., Wilde K. (2021). Repeated projectile impact tests on multi-layered fibrous cementitious composites. International Journal of Civil Engineering, 19, 635-661. DOI: 10.1007/s40999020-00595-4.

8. Haridharan, M.K., Matheswaran, S., Murali, G., Abid, S.R., Fediuk, R., Amran, Y.H.M., Abdelgader, H.S. (2020). Impact response of two-layered grouted aggregate fibrous concrete composite under falling mass impact. Construction and Building Materials, 263, DOI: 10.1016/j.conbuildmat.2020. 120628.
9. Abdelgader, H.S., Fediuk, R.S., Kurpinska, M., Khatib, J., Murali G., Baranov, A.V., Timokhin, R.A. (2019). Mechanical properties of two-stage con-crete modified by silica fume. Magazine of Civil Engineering, vol. 89, no. 5, 26-38. DOI: 10.18720/MCE.89.3.

10. Rajabi, A.M., Moaf, F.O., Abdelgader, H.S. (2020). Evaluation of mechanical properties of two-stage concrete and conventional concrete using nondestruc-tive tests. Journal of Materials in Civil Engineering, vol. 32, no. 7, DOI: 10. 1061/(ASCE) MT.1943-5533.0003247.

11. Abdelgader, H.S. (1996). Effect of quantity of sand on the compressive strength of two-stage concrete. Magazine of Concrete Research, 1996, vol. 48, no. 177, 353-360. DOI: 10.1680/macr. 1996.48.177.353.

12. Abdelgader H.S. (1999). How to design concrete produced by a two-stage concreting method. Cement and Concrete Research, vol. 29, no. 3, 331337, DOI: 10.1016/S0008-8846(98)00215-4.

13. Abdelgader, H. S., Górski, J. (2003). Stress-strain relations and modulus of elasticity of two-stage concrete. Journal of Materials in Civil Engineering, vol. 15, no. 4, 329-334, DOI: 10.1061/ (ASCE)08991561(2003)15:4(329)

14. Dehn, F., Holschemacher, K., Weiße, D. (2000). Self-compacting concrete (SCC), time development of the material proper-ties and the bond behaviour. LACER, no. 5, 115-124.

15. Murthi, P., Awoyera, P., Selvaraj, P., Dharsana, D., Gobinath, R. (2018). Using silica mineral waste as aggregate in a green high strength concrete: workability, strength, failure mode, and morphology assessment. Australian Journal of Civil Engineering, vol. 16 , no. 2,1-7. DOI: 10.1080/14488353.2018. 1472539

16. Persson, B. (2001). A comparison bet-ween mechanical properties of self-compacting concrete and the corres-ponding properties of normal concrete. Cement and Concrete Research, vol. 31, no. 2, 193198, DOI: 10.1016/S0008-8846(00)00497-X.

17. Okamura, H., Ouchi, M. (2003). Self compacting concrete. Journal of Advan-ce Concrete Technology, vol. 1, no. 1, 5-15, DOI: 10.3151/jact.1.5

18. Rajesh, M., Pitchaimani, J., Rajini, N. (2016). Free vibration characteristics of banana/sisal natural fibers reinforced hybrid polymer composite beam. Proce-dia Engineering, 144, 1055-1059, 10.10 16/j. proeng.2016.05.056

19. May-Pat, A., González, A.V., Herrera-Franco, P.J. (2013). Effect of fiber surface treatments on the essential work of fracture of HDPE-continuous henequen fiber-reinforced composites. Polymer Testing, vol. 32, 1114-1122. DOI: 10.1016/j.polymertesting.2013.06. 006 
20. Mukhopadhyay, S., Fangueiro, R., Yusuf, A., Şentürk, Ü. (2008). Banana fibers-variability and fracture behaviour. Journal of Engineering Fibers and Fabrics, vol. 3, no. 2. DOI: 10.1177/ 155892500800300207.

21. Mustafa, W.A., Saidi, S.A., Zainal, M., Santiagoo, R. (2018). A proposed compatibilizer materials on banana skin powder (BSP) composites using different temperature. Journal of Advance Research in Fluid Mechanics and Thermal Science, vol. 43, no. 1, 121-127.

22. Chandak, A., Agrawal, N., Thakur, D., Titiksh, A. (2016). Analysis of self compacting concrete using hybrid fibres. International Journal of Trend in Research and Development, vol. 3. No. 2, 641-645.

23. El-Nadoury, W.W. (2020). Applicability of using natural fibers for reinforcing concrete. IOP Conf. Series: Materials Science and Engineering 809. DOI:10.1088/1757-899X/809/1/012018

24. EFNARC. (2005). The European guideline for self compacting concrete. Specification. Production and Use.

25. Nurwidayati, R., Fardheny, A.F., Asyifha. (2021). Investigation on me-chanical properties of fiber reinforced concrete. IOP Conf. Series: Earth and Environmental Science, vol 758, no.1. DOI:10.1088/1755-1315/758/1/012016
26. Khan, M., Rahamathbaba, S., Mateen, M.A., Shankar, D.V.R., Hussain, M.M. (2019). Effect of $\mathrm{NaOH}$ treatment on mechanical strength of banana/epoxy laminates. Polymers from Renewable Resources, vol. 10, no. 1-3, 19-26, DOI: 10.1177/2041247919863626

27. Wijianto., Ibnu, R.M.D., Adityarini, H. (2019). Effect of $\mathrm{NaOH}$ concentration treatment on tensile strength, flexure strength and elasticity modulus of banana fiber reinforced. Material Science Forum, vol. 961, 1015. DOI:10.4028/www.scientific.net/MSF.961.10

28. Jasbi, M.S., Hasani, H., Zadhoush, A., Safi, S. (2017). Effect of alkali treatment on mechanical properties of the green composites reinforced with milkweed fibers. The Journal of Textile Institute, vol. 109, no. 1, 24-31. DOI: 10.1080/ 00405000. 2017.1320816.

29. Chandrasekar, M., Ishak, M.R., Sapuan, S.M., Leman, Z., Jawaid, M. (2017). A review on the characterisation of natural fibres and their composites after alkali treatment and water absorption. Plastic, Rubber and Composites Macromolecular Engineering, vol. 46, no. 3, 119-136, DOI: 10.1080/1465801 1.2017.1298550. 